\title{
Health Afflictions and Quality of Work Life among Women Working In Fireworks Industry
}

\author{
K. M. Ashifa, P. Ramya
}

\begin{abstract}
All festivities see colors in the form of fireworks. Most of the firework goods that India put away are factory-made from Sivakasi, a city in Virudhunagar District in the state of Tamil Nadu. The Industrialized procedure in the Firework industries includeslabor-intensivemanagement of many chemicals. Therefore firework industries are identified to be highly dangerous. The purpose of this research is to review the health afflictions and quality of work life for firework working women. As per the respondents views the current study focuses on health afflictions and quality of work life of women workers working in fireworks. The paper tries to asses about the health affiliations and quality of work life of working women in fire work industries. The required primary data is collected from Anaiyur village which is located in Sivakasi.In that village nearly 382 women's were working in a particular fire workindustry.
\end{abstract}

Keywords: Fireworks industry, Women Workers, Health afflictions, Quality of Work life.

\section{INTRODUCTION}

In Sivakasi, fireworks industries are established, mainly in rural areas. The fireworks industry is one of the dangerous industries. There are around 750 factories and 80000 workers are employed in them. This study assumes significance due to the above- mentioned truths (DhruvKatoria,2013). Fireworks are a class of low explosive pyrotechnic devices used for aesthetic and entertainment purposes. The most common use of a fireworks display, a display of the effects produced by firework devices. Fireworks struggles are also regularly held at a number of places.Fireworks take many forms to produce the four primary effects: noise, light, smoke, and floating materials.It can lead to headaches and reduced mental perception. It has much more severe effects in people with hearts, breathing or nervous system disorders. Fireworks can also cause respiratory problems such as: Chronic or allergic bronchitis, bronchial asthma, sinusitis, rhinitis, pneumonia and laryngitis. The fireworks chemical causes irritation to skin and eyes. Delay exposure may affect kidney, white blood cells and thyroid.It irritates the nose, throat and lungs. The women work in a hazardous situation by using lot of chemicals which can even reason death. Hence, this study has been taken uptoknow the health issues of women workers in fireworks industries. The current study is undertaken to discover the problems faced by the women laborers in fireworks industries in Sivakasi. Women workers involved in fireworks industry in a specific district of Tamil Nadu, India. Virudhunagar district is a southern district of Tamil Nadu. As distant as the SivakasiTaluk in

Revised Manuscript Received on 14 August, 2019.

Dr.K.M.Ashifa, Assistant Professor, Department of Social Service, Faculty of Health Science, Istanbul Gelisim University, Istanbul, Turkey

Ms. P. Ramya,Assistant Professor, Department of Social Work ,Kalasalingam University, Tamil Nadu, India
Virudhunagar district is anxious, crackers making is one of the main disorganized industries. This fireworks industry enhances the economy. Most of the workers in this industry are women; the manufacture of crackers is mainly lies in the hands of women. Quality of Work Life is related to activities which takes place at each level of an organization, and which at the same time enhance human dignity and growth and encourage greater organizational effectiveness. Hence, it is appropriate here to make an effort to identify the most important sizes that give to the enhancement of Quality of Work Life under different perceptions workers in fireworks industry. The increase of production in such industries mostly is contingent on their health problems and quality of work life. Already, a number of studies has been undertaken to study women workers in different units. The present study focuses on the health problems and quality of work life of women workers in fireworks productions. The women fire workers are illiterate and of poor economic background. The production of crackers involves chemicals, which can be absorbed into the body where it affects the bones, skins, teeth of growing children and urinal problems of women's. Also, younger lungs are more vulnerable to irritation and damage from noxious fumes. Sivakasi is known for rural women workers in fireworks industries. The most mutual reported health difficults to workers working in the fireworks are related to overexertion, interaction with substances or tools, reductions, human reaction or effort, or being smash into by an object. As amanager,heshould take every conceivablechanceto demonstration his workers that you are enthusiastic to health and safety performs by attractiveaggressively involved. The second section deals with the quality of work life among women workers in fireworks industries are discussed.(R.C.SaravanaKumar ,Dr.G.Karunanidhi, 2016).

\section{REVIEW OFLITERATURE}

A number of studies has been undertaken to study women workers in different units. The present study focuses on the health problems and quality of work life of women workers in fireworks productions. An analysis of literature review is as follows: In the study is Perumalammal (2015) in her study titled "Women workers of fireworks industrial unit in Thayilpatti, Kamarajar District "has investigated the working and alive conditions of women workers in fireworks industry. The study is based on 56 fireworks industries of Kamarajar Area. The researcher experiential

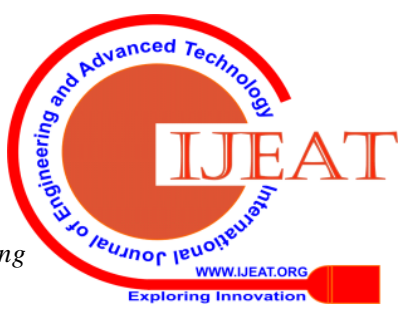


that the working situations of women workers in the industry taken up for study were unacceptable because they were troubled with long hours of work, low wages, and poor health and the alike. According to JnaneswarK.(2016) - Study on the Equal of Quality of Work Life Expert by the Employees of fireworks unit in Sivakasi. In the study researcher study efforts to treasureavailable the level of quality of work life among the employees of public sector units in Sivakasi and also finds that female employees are experiencing the same level of Quality of worklife.

Kamali C. (2005) in her study titled "women worker in match and firework divisions at Sivakasi" has studied the socio-economic conditions of women worker working in match and fire units. By way ofeach the study, it is perfect that the conditions of the women worker were moving.

Esakky S. (2004) in his study titled "On the economic and social values of women worker employment in fireworks industryinaboutSivakasi in Tamilnadu" stressed that the women worker in Sivakasi cannot be eliminated without the welfare of their families and the socio-economic conditions are significantly developed.

\section{NEED AND SIGNIFICANCE OF THE STUDY}

The need of this study remains broader. This may help to find out a satisfactory solution to this problem. The study is confined to evaluation of the women worker's problems in the fireworks industry in the study area. The study is expected to provide an insight keen on the issues of quality of work life of the workers.

\section{OBJECTIVES OF THE STUDY}

The study aims to know the socio demographic details of women working in fireworks industry. It also tries to identify the health afflictions of the women's in fireworks industries. Further the study is taken to analyze the Quality of life of women workers in Fireworks Industries. Suggestive measures to improve the Situation of Women working in Fireworks industry are alsoidentified.

\section{METHOD OF THESTUDY}

This study created on primary data. Primary data were collected from 80 sample respondents working in fireworks industries using stratified random sampling methods. The collected data were analyzed with the help of interview schedule methods. The study helps to know about the fireworks women's health affliction'. The study would throw more positive on the problems of the current fireworks industry workers. Further, it may cover method for an improvement of socio - economic conditions, health problems, welfare measures, safety problems in the fireworks industry among the women workers in the study area. Both the factors, namely health problems, welfare measures and safety problems providing by the fireworks industry in the study are to be taken into consideration while trying to find out preparations for thismalady.

\section{RESULT ANDDISCUSSION}

The present study analyzes the health affliction and the quality of work life among working women's now Fireworks industry. It is important to ensure proper design of the interview schedule. For women workers the survey takes into account the main issues concerning those relating to individual data, income data, spending data and the problems that they are facing. The interview schedule comprises with the socioeconomic and spending pattern of female workers like age, education, family status, marital status, and income, spending pattern like expenditure on food, rent, other outflow and the problems that they are facing. The study examined the social demographic particulars to analyze the health problems solicitation of the women. Maximum working women feel that they certainly undergo health related problems like physical and mental stress overall weakness extraextreme work capacity because of work pressure, family pressure etc. Human resource remains an important factor of manufacture whose performance and productivity cannot be provided proper human resource management depends on the various factors including quality of work life it is on suitable term in the field of Human Resource Management it is essential for organization to continue attract and retain valuable labour forces the term of quality of work life refers to the favorable or unfavorable of a total job environment of the people it has been observed that $83.8 \%$ percentage respondents said that the quality of worklife improve the livingstandard.Nearly $78.8 \%$ percentage of respondents have mild body pain due to long working hours and $81.2 \%$ of the respondents are having breathing problem, $50 \%$ half of the respondents are having headaches, the majority of $85.5 \%$ percentage of respondents have mild mental strain of a given to the workplace nowadays due to stress and pressure women were affected mentally there is a researcher analyzed that $76.2 \%$ percentage of respondents cause depressive disorder and majority of the treatment $92.5 \%$ respondents are taking allopathy. Majority of the respondentsworkingconditions is $92.5 \%$ saying average conditions, $83.8 \%$ of the respondents work load is very much but due to participative environment employees are able to complete their task,and83.8 percentage respondent's they are have increasing the respondents Quality of work life in your company improves your living standard forare the researcher has applied the factor study to analyze the factor influencing the opinion of workers towards the quality of work life the level of workers satisfaction Quality of work life is measured to levels of satisfied and dissatisfied.The other issues are known to be minimum health problems among women labourers in fireworks industries.Based on the socio - cultural traits, women health issues and quality of work life among the women workers in fireworks industries.in thisresearch

\section{CONCLUSION}

The researcher in her study titled "health afflictions and quality of work life among women working in fireworks industry in Sivakasi" has carried out an elaborate study on the various factors that were causative to health issues among women workers in fireworks industry. The researcher took for her study the trends prevailing in the study area. 90 percent of Indian fireworks industries are

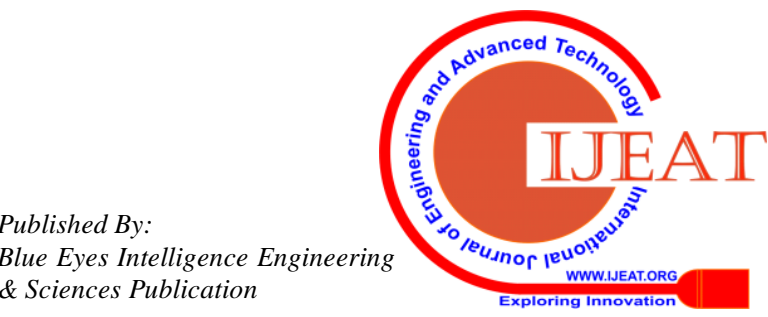


located in Sivakasi, Tamil Nadu and hence the women workers there are the most affected health issues. The researcher has come to the conclusion with regards to fireworks working women health issues and quality of work life among the respondents. The researcher has offered some implementable suggestions are in the study area women workers. It is recommended that necessary facilities such as rest room, sick rooms, and Creech facilities etc. can be provided for better quality of work life. The women workers are to deal with dignity based on the industry. Good relationship should be maintained within the working women to make the climate healthy. The workers may be provided monthly check ups, Creating freedom, positive feeling and creating autonomous for group. The organization can introduce new health programs like educating employees about their health for sick leaves etc. The organization cantrytocreatehighlevelofjobinvolvementand job satisfaction which tends high productivity. Careerdevelopment of the women workers is to be taken care of to balance work life. The management should come forward and increase the wages as per government norms. The management should create awareness to workers. Providing primary healthcare centers in the industries premises for financial and administrative support can also be done, which if implemented would go a extended way in bettering the lives of working women specifically in fireworks industry. Hence this study helps in promoting effectual actions to remove obstacle of working women health conditions and quality of work life todevelop.

\section{REFERENCES}

1. Ashifa, K.M. (2019) Impact of Hydrocorbon Extraction in Neduvasal: A Psycho- Social Assessment, International Journal of Innovative Technology and Exploring Engineering, 8(9S2): 685-687.

2. Azahurajan.A, selvakumar.N, suresh.A, 2014 "Environmental friendly fireworksmanufacturing using nano scale flash powder", journal of scientific \& industrial research, 73,479-484.Bahnisikha Gosh and SudhinK.Mukhopadhyay "displacement of the female in the Indian labour force". Economic and political weekly, vol. 19, no.47 (nov. 24, 1984), pp. $1998-2002$.

3. Celia. B.R \&Karthick.M. (2012).A Study on Quality of Work Life in the IT Sector. Asia Pacific Journal of Research in Business Management, APJRBM, 3(2), 27- 35.

4. Chitale, C.M \&DeeptiLele. (2012).Employees perception on Quality of Work Life in Police Department with Special Reference Pune Police. South Asian Academic Research Journal, An International Multidisciplinary Research Journal, ACADEMICIA,2(10),260-275.

5. Dr.R.SophiaPorchelvi, P.Jamuna Devi, 2015, "Regression Model for the People working in Fire Work IndustryVirudhunagar District", International Journal of Scientific and Research Publications, Volume 5, Issue4.

6. DhruvKatoria, Dhruv Mehta, DhruvSehgal and Sameer Kumar, 2013, "A Review of Risks to Workers Associated with Fireworks Industry", InternationalJournalof Environmental Engineering and Management, 4(3), 259-264.

7. Female work participation and economic development: A Regional KamlaNath economic and political weekly. Vol. 5, no. 21 (May 23. 1970), pp. $846-849$.

8. Harish Metha\&Thandavan.R., (2011). Work Environment Factors in QWL among College Teachers in Chennai, Southern Economist, 50 (12), 15-18

9. jnaneswar.k, 2016, Indian journal of management 9(5),A study on the level of quality of worklife experienced by the Employees of fireworks unit in Sivakasi.33- 44.

10. Kamala Nath "Women in the working force in India" economic and political weekly, vol.3, no.31 (aug.3, 1968), pp.1205-1213
11. K. Hymavathi, Dr. A.B. Saraswathi, 2018, "A study on the concept of quality of work life with respect to jute industry- a literature review", International Journal of Civil Engineering and Technology (IJCIET) Volume 9(1),597-607.

12. Kamini B. Dashora "problems faced by working women in India". International Journal of Advanced Research in Management and Social Sciences, Vol. 2 |No. 8 August2013.

13. Mohanasundaram. (2011).A Study on Quality of Work Life in Tamil Nadu Newsprint and Paper Limited, Karur. International Journal of Research in Computer Application \& Management, 1(8),53-58.

14. Mohan \& Ashok, Measuring of Quality of Work Life in Textile Industries - An Integration of Conceptual Relationship with Productivity. (2011).International Journal of Research in Commerce and Management, 2(4),67-70.

15. PremaManoharan. (2011).Quality of Work Life among Bank Professionals: A Study Undertaken at Indian Bank, Chennai”, International Journal of Research in Commerce, Economic \& Management. 1(8),69-74.

16. SaravanaKumar, R.C. ,Dr.G.Karunanidhi , 2016, "Health Problems of Women Labourers in Fireworks Industries - A Cross Sectional Study",5(6).

17. Srinivasan S. and Ilango P. "occupational health problems of women migrant workers in thogamalai, Karur district, Tamil Nadu, India" international research journal of social sciences vol. 2(2), , February (2013) pp.21-26

18. Thiruvasagam G. Rajasekar D. Vettriselvan R. Profile and Problems of Women Domestic Workers in Mangochi, Malawi, International Journal of Recent Technology and Engineering, 2019: 8(2S3): 1167-1171

19. Vettriselvan, R., Antony JesuRajan, F. S. A., \&Arunkumar, N (2019). Occupational health issues faced by women in spinners. Indian Journal of Public Health Research and Development 10(1), 500-504.

20. Vettriselvan R. Ruben Anto. JesuRajan FSA. Pathetic Health Status and Working Condition of Zambian Women, Indian Journal of Public Health Research \& Development, 2018;9(9):259-264.

21. Vettriselvan, R., Rengamani, J., James, F.A., Srinivasan, R., Poongavanam, S. Issues and challenges of women employees in Indian technical industries International Journal of Engineering and Advanced Technology, 2019: 8(2S2): 404-409.

22. .https://www.worldwidejournals.com/international-journal-ofscientific-research-(IJSR)/file.php?val=June_2016_1465050570 182.pdf.

23. http://www.trp.org.in/issues/quality-of- work-life-of-womenemployees-in-fireworks-and-match-industries-in-Sivakasi-tamilnadu.

24. http://www.fireworks.com/fireworks-university/historyfireworks

25. http://www.ripublication.com/ ijeem.ht

26. http://hdl.handle.net/10603/5670 